\title{
If Everything Has Changed, Why Such a Focus on Bailing Out Capitalism? The Somber Reality Underpinning Covid-19
}

\author{
Paul R. Carr ${ }^{1}$ \\ Published online: 1 May 2020 \\ (C) Springer Nature Switzerland AG 2020
}

Keywords Democracy capitalism $\cdot$ Covid-19·Pandemic $\cdot$ Economy $\cdot$ Social justice $\cdot$ Social solidarity

\section{Introduction}

Everything seems out of whack, and we are not sure where to turn, what to touch, when to move, and how to get out of this. The dire, catastrophic, dystopian reality of people being infected, contaminated, falling ill, and dying is real, almost too real. At the same time, lots of folks insist that it is hoax, a conspiracy, that it is not as bad as people think. Images of military trucks carrying corpses to their final resting place in Italy are juxtaposed with thousands of young university students having the time of their lives, together, in a party-mode, on the beaches in Florida. No one is sure how it will end as many or most of us stay at home, self-distancing, self-quarantining, and self-reflecting on what it all means.

I'm thinking a lot these days about the priorities, resources, decision-making, and political handling and framing of the Covid-19 pandemic in real time. Of course, what I/we say and think today will most likely change tomorrow. But there are signposts, historical knowledge, empirical research, and lived experience to help us consider what is really going on.

How has democracy fared so far? I'm thinking of the normative, representative, hegemonic democracy that we all know, live, and experience, the one with constrained elections, limited political parties, corporatized media jingoism, neoliberal education, and weakly encouraged citizen participation outside of the prescribed framework (see Carr and Thésée 2019).

Paul R. Carr

prcarr@gmail.com

1 Département des sciences d l'éducation, Université du Québec en Outaouais, 283, Boulevard Alexandre-Taché, C.P. 1250, succursale Hull, Gatineau, Québec J8X 3X7, Canada 
I consume far too much mainstream media and am confronted with and by it even when I do not consume it. It is everywhere; the ideas, concepts, personalities, and messages are disseminated widely, broadly, swiftly, and unquestionably throughout all platforms, infused into family discussions, community dialogue, and political discourse, and then pushed through the educational meat grinder. Offering alternative notions, assumptions, questions, and realities is often met with stares of incredulity and stupefaction. Not by everyone, of course, and there is enormous solidarity and wonderful, transformative work, engagement, and change happening around the world. But the formal sectors - the fundamental governmental structures, the international organizations, and the education systems - are also (or should be) required to create a more meaningful, critically engaged democracy.

\section{Covid-19 and the Economy}

I'm particularly interested at this time in how the economy, despite clearly obvious health efforts, concerns, and evidence, continues to shape, pervade, and overarch the context of the pandemic we are facing. I'm not suggesting that there is no emphasis placed on doing what is absolutely necessary at this time nor that public health measures and communications are not a central feature of our collective, global reality. However, a quick perusing of the media can provide a rough sketch or environmental scan of how health/survival is being trumped (please excuse the inadvertent pun) by investor/economic interests.

There are so many reports, media outlets, platforms, sources and producers (vloggers, bloggers, citizen journalists), and types of engagement that it would be quite easy to get lost in the sea of distortion and messaging. I present a few media reports below in an attempt to weave together a narrative of the overarching hegemonic interests that distract, normalize, and condition the broader public to support, empathize with, and converge, if not vehemently exposed and critiqued, toward capitalist economic thinking. I am not, in any way here, trying to diminish the real, tangible, and material concerns of working people, who are enmeshed in the complete meltdown of entire sectors of the economy, including tourism, hospitality, the arts and culture, and airlines. We are all affected but some are affected quite disproportionately. The vulnerable are more vulnerable than ever of contracting the virus, of sustaining satisfactory living conditions, and of influencing 'democracy'.

At first glance, foregrounding the pandemic is the extreme attention paid to the stock market. Leading the charge, the US Secretary of the Treasury, Steve Mnuchin, believes that the "coronavirus pandemic [is] "a great investment opportunity"' (Forgey 2020).

This is a short-term issue. It may be a couple of months, but we're going to get through this, and the economy will be stronger than ever, Mnuchin told CNBC in an interview.

'You know, I look back at people who bought stocks after the crash in 1987, people who bought stocks after the financial crisis,' he continued. 'For long-term investors, this will be a great investment opportunity'. (Forgey 2020) 
The personal wealth-aggrandizement carousel can be exemplified by a Democracy Now (2020b) report on how several US senators used confidential briefings to exploit their personal stock portfolios.

Calls are growing for a number of U.S. senators to resign, following reports they sold millions of dollars' worth of stocks after receiving privileged briefings about the threat of coronavirus to the global economy. ProPublica reports Republican Richard Burr, the chair of the Senate Intelligence Committee, unloaded as much as $\$ 1.7$ million of his holdings on February 13 in 33 separate transactions. At the time, he had access to classified information about the coronavirus and was receiving daily intelligence briefings. The stock market began plummeting a week after Burr's sales and has since lost about $30 \%$ of its value. (Democracy Now 2020b)

A New York Times report unveils nefarious business dealings in which a company in Germany working on the coronavirus vaccine is being surveilled for a potential takeover by US interests, 'prompting German politicians to insist no country should have a monopoly on any future vaccine' (Reuters 2020). We can add to this the twisted nature of financial hegemony with the example how 'Italians found on way to 3D print key ventilator piece for $\$ 1$ to help battle coronavirus - so the company with the patent is threatening to sue':

After two Italian volunteers used a 3-D printer to manufacture a desperately needed ventilator component for those stricken by the coronavirus, the medical company with the patent for the device threatened to sue - even as the printed valves saved at least 10 people's lives in a hospital in the northern Italian city of Brescia. (Higgens 2020)

Concurrently, measures are being taken that explicitly indicate that a free-market, investor-based political culture is ill-prepared to protect the people. For instance, '[t]he Ministry of Health in Prime Minister Pedro Sánchez's administration on Monday announced it would put all of Spain's private health providers and their facilities into public control as the spread of COVID-19 continues to grip the country' (Payne 2020). Questioning if the private sector can adequately respond to the healthcare needs of the populace, not only during pandemics but also at all times, should not be a theoretical question.

The mainstream media culture, meshed with evasive normative political structures, also lays bare the foolhardiness of what is truly important. How many reports on the production, consumption, and purchase of toilet paper must be generated? At the same time, military campaigns continue; arms are manufactured, sold, purchased, and used. Military conflict has not stopped, neither have blockades, embargoes, and sanctions, ensuring that the coronavirus will undoubtedly affect a plethora of innocent victims.

Pilkington (2020) of The Guardian exposes how 'US sales of guns and ammunition soar amid coronavirus panic buying.' The focus is not on respirators, hospital beds, and trained staff for many. 
Larry Hyatt, owner of one of the country's largest gun shops, Hyatt Guns in Charlotte, North Carolina, told the Guardian that the scenes of mass buying at his store were virtually unprecedented. 'This is only the second time in my 61 years of business that we've seen anything like this,' he said, adding that the first occasion was the aftermath of the mass shooting at Sandy Hook elementary school in Connecticut in $2012 \ldots$.

Hyatt said that the type of guns being bought was reflective of the fear prevalent among customers. There was almost no interest in hunting rifles. Instead, people were opting for target guns and there was big demand for AR-15 semi-automatic assault-style rifles.

Asked why he thought the spike was happening, Hyatt replied: 'Financial meltdown, pandemic, crime, politics ... you throw it all into the pot, and you have one hell of a mess.' (Pilkington 2020)

The bailout pressure is enormous at this time to soften the potential collapse of capitalist foundations. Who should be protected, how, to what degree? We all remember the disastrous stimulus package of the Obama administration's first term, in which bankers largely profited to the behest of working people (Taibbi 2013). The rhetoric is already leaning toward massive amounts that may not fully assist or alter the already highly inequitable equation that places may people in debt, in poverty, and in a state of hopelessness. Tankersley and Casselman (2020), in a New York Times report, highlight the disproportionate ramifications of what is likely to transpire:

To blunt the fallout, Washington is weighing proposals that could easily top $\$ 2$ trillion, a staggering jump from the initial $\$ 8.3$ billion virus response bill lawmakers approved this month. That includes a $\$ 1$ trillion request President Trump floated with Congress on Wednesday, which would provide direct payments to individuals and small businesses, along with aid for airlines and other affected industries....

Payments to large companies could prove trickier. Many of the companies now asking for government support received a big corporate tax break from Mr. Trump's 2017 tax cuts and have spent years returning cash to shareholders in the form of stock buybacks and dividends. That has drawn criticism from Democratic lawmakers, who accuse big companies of moving jobs out of the United States and putting shareholders ahead of workers, whose wages have risen only modestly since the last recession ended in 2009.

The four biggest American airlines collectively bought back $\$ 39$ billion in stock from 2015 to 2019 and paid out \$6 billion in dividends, according to data from Capital IQ. The companies that make up the broader S\&P 500 index spent more than $\$ 5$ trillion in buybacks and dividends over that period. (Tankersley and Casselman 2020)

At the same time, 'banks pressure healthcare firms to raise prices on critical drugs, medical supplies for coronavirus': 
IN RECENT WEEKS, investment bankers have pressed health care companies on the front lines of fighting the novel coronavirus, including drug firms developing experimental treatments and medical supply firms, to consider ways that they can profit from the crisis.

The media has mostly focused on individuals who have taken advantage of the market for now-scarce medical and hygiene supplies to hoard masks and hand sanitizer and resell them at higher prices. But the largest voices in the health care industry stand to gain from billions of dollars in emergency spending on the pandemic, as do the bankers and investors who invest in health care companies.

Over the past few weeks, investment bankers have been candid on investor calls and during health care conferences about the opportunity to raise drug prices. In some cases, bankers received sharp rebukes from health care executives; in others, executives joked about using the attention on Covid-19 to dodge public pressure on the opioid crisis. (Fang 2020).

The last vignette that I would like to present relates to the Canadian agricultural sector, and how 'Migrant workers help grow our food. Coronavirus is leaving them in limbo' (Chiu and Saba 2020). At a time when all countries are closing borders, limiting or preventing immigration, even tourism, and when there is extreme concern about the transmission of the virus, it seems odd, if not outright totally disjointed, that Canada, and it is probably not the only country in this position, would seek out workers from the Global South to work for a minimal amount when there is no doubt that unemployment will be on the rise at home. Moreover, it is equally striking that many reject global interaction and connection-I'm not talking about neoliberal 'globalization' herewhile insisting on exploiting cheap labor. If these laborers are not brought into the country, will the crops not be picked, will Canadians not eat, will companies and farms go under? These are important questions at a time when efforts to save the economy are at the center of formal deliberations, yet bailouts for the cruise, hotel, financial, retail, and cultural sectors do not seem to extend to the agricultural field. What is at play here? Can we eat only if wages are low for the people bringing it to our tables? And this is not a problem that arises only during pandemics.

\section{Conclusion}

We're all in this together, or supposed to be. Yet, it would appear that, as has been the ritual in past crises as so eloquently presented by Naomi Klein in relation to the shock doctrine during capitalist crises, some people, elites, groups, and interests are taking advantage of the situation, or are preparing to do so (Democracy Now 2020a). Why do societies continue to uphold social inequalities while also presenting strategies to stem the tide of Covid-19? I use 'societies' in a generic sense, knowing full well that the most vulnerable and marginalized will continue to be so during and after the pandemic unless massive social solidarity and social mobilization is ignited.

If so many supposedly finite resources are available for financial bailouts, why not provide enhanced, universal healthcare in the first place? Why not address the legitimate concerns of the gilets jaunes, who have been protesting the streets in France for 
the past year? Why not fully address the underlying conditions that promote, enhance, and solidify social inequalities? If funds are available for the military, how can this be considered a societal investment? How do we stand by in the face of the continuous cultural genocide of Indigenous peoples? And what is the connection to democracy? Maintaining these social inequalities makes no economic sense, yet changing the systems, structures, and values that underpin them is a spectacularly arduous and debilitating task.

An example that troubles and disrupts my thinking is the Canadian Prime Minister Justin Trudeau's principled stand at present, arguing that ' $[\mathrm{n}] \mathrm{o}$ one should have to worry about paying rent, buying groceries, or additional child care because of COVID19. We will help Canadians financially (Hall and MacSweeney 2020). I agree fullheartedly and would also agree that this should not be the case when there is no pandemic. The case is made over and over that resources are too limited to assist those facing the greatest challenges, yet, during a time of crisis, the will to find these resources is significant.

In sum, the economy is important. But so is social justice and public health. If and when we make it through the Covid-19 tunnel, it will be important to allow for a reimagining of democracy, sharing resources, and social solidarity. This is much easier said than done. But the potential to work together, across identities, borders, experiences, and philosophies to achieve a more global assessment, engagement, and solidarity to confront global challenges, such as pandemics, and, notably, the environment, should be a worthy and necessary political project.

\section{References}

Carr, P., \& Thésée, G. (2019). “It's not education that scares me, it's the educators...”: is there still hope for democracy in education, and education for democracy? Gorham: Myers Education Press.

Chiu, J., \& Saba, R. (2020). Migrant workers help grow our food. Coronavirus is leaving them in limbo. The Star, 18 March. https://www.thestar.com/news/canada/2020/03/17/migrant-workers-help-grow-our-foodcoronavirus-is-leaving-them-in-limbo.html. Accessed 21 March 2020.

Democracy Now (2020a). “Coronavirus capitalism”: Naomi Klein's case for transformative change amid coronavirus pandemic. 19 March. https://www.democracynow.org/2020/3/19/naomi_klein_coronavirus_ capitalism. Accessed 21 March 2020.

Democracy Now (2020b). At least five U.S. senators, briefed on coronavirus, sold stocks before market crash. 20 March. https://www.democracynow.org/2020/3/20/headlines/at_least_five_us_senators_briefed_on_ coronavirus_sold_stocks_before_market_crash. Accessed 21 March 2020 .

Fang, L. (2020). Banks pressure health care firms to raise prices on critical drugs, medical supplies for coronavirus. The Intercept, 19 March. https://theintercept.com/2020/03/19/coronavirus-vaccine-medicalsupplies-price-gouging/. Accessed 21 March 2020.

Hall, M., \& MacSweeney, C. (2020). No Canadian should have to worry about paying rent amid COVID-19 pandemic: Trudeau. News 1130, 13 March. https://www.citynews1130.com/2020/03/13/no-canadianshould-have-to-worry-about-paying-rent-amid-covid-19-pandemic-trudeau/. Accessed 21 March 2020.

Forgey, Q. (2020). Mnuchin calls coronavirus pandemic ‘a great investment opportunity'. Politico, 13 March. https:/www.politico.com/news/2020/03/13/mnuchin-coronavirus-investment-opportunity-128132. Accessed 21 March 2020.

Higgens, E. (2020). Italians found way to 3-D print key ventilator piece for $\$ 1$ to help battle coronavirus- so the company with the patent is threatening to sue. Common Dreams, 18 March. https://www. commondreams.org/news/2020/03/18/italians-found-way-3-d-print-key-ventilator-piece-1-help-battlecoronavirus-so. Accessed 21 March 2020. 
Payne, A. (2020). Spain has nationalized all of its private hospitals as the country goes into coronavirus lockdown. Business Insider Australia, 16 March. https:/www.businessinsider.com/coronavirus-spainnationalises-private-hospitals-emergency-covid-19-lockdown-2020-3. Accessed 21 March 2020.

Pilkington, E. (2020). US sales of guns and ammunition soar amid coronavirus panic buying. The Guardian, 16 March. https://www.theguardian.com/world/2020/mar/16/us-sales-guns-ammunition-soar-amidcoronavirus-panic-buying. Accessed 21 March 2020.

Reuters. (2020). Germany tries to halt U.S. interest in firm working on coronavirus vaccine. The New York Times, 15 March. https://www.nytimes.com/reuters/2020/03/15/world/europe/15reuters-healthcoronavirus-germany-usa.html. Accessed 21 March 2020.

Taibbi, M. (2013). Secrets and lies of the bailout: the federal rescue of wall street didn't fix the economy-it created a permanent bailout state based on a Ponzi-like confidence scheme and the worst may be yet to come. The Rolling Stone, 4 January. https:/www.rollingstone.com/politics/politics-news/secrets-and-liesof-the-bailout-113270/. Accessed 21 March 2020.

Tankersley, J., \& Casselman, B. (2020). Washington weighs big bailouts to help U.S. economy survive coronavirus. The New York Times, 18 March. https://www.nytimes.com/2020/03/18/business/bailouteconomy-coronavirus.html. Accessed 21 March 2020. 